\title{
The Suitability of a Greater ChInA CurRenCy UNION
}

\author{
YIN-WONG CHEUNG \\ JUDE YUEN
}

CESIFO WORKING PAPER NO. 1192

CATEgORY 6: MONETARY POLICY AND INTERNATIONAL FINANCE

MAY 2004

\footnotetext{
An electronic version of the paper may be downloaded

- from the CESifo website:

www.CESifo.de
} 


\title{
The Suitability of a GREATER ChINA CURRENCY UNION
}

\begin{abstract}
The study assesses the level of integration among the three Greater China economies (namely China, Hong Kong, and Taiwan) and examines the suitability of a Greater China currency union. Currently, the three economies have extensive trade and investment linkages. Our analyses show that these economies share common long-run and short-run cyclical variations. We also estimate the output costs of relinquishing policy autonomy to form a currency union. The estimated output losses, which depend on, for example, the method used to generate shock estimates, seem to be moderate and are likely to be less than the efficient gains derived from a currency union arrangement.
\end{abstract}

JEL classification: F33, F31, F41.

Keywords: Greater China, trade and investment, common stochastic trend, synchronized and non-synchronized business cycles, output losses, exchange rate regime.

\author{
Yin-Wong Cheung \\ Economics Department \\ University of California \\ Santa Cruz, CA 95064 \\ U.S.A. \\ cheung@ucsc.edu
}

\author{
Jude Yuen \\ Economics Department \\ University of California \\ Santa Cruz, CA 95064 \\ U.S.A. \\ jnyuen@yahoo.com
}

The authors thank the seminar participants at the Peking University and Shandong University for their comments and suggestions. Also, we thank Desmond Hou and Dickson Tam for compiling the data. The financial support of faculty research funds of the University of California, Santa Cruz is gratefully acknowledged. Part of the project was completed while Cheung was visiting the Hong Kong Institute for Monetary Research, and he thanks the Institute for its hospitality. The views contained herein are solely those of the authors. 


\section{Introduction}

The economic entity comprising of China, Hong Kong, and Taiwan is referred to by different names. The common ones include Greater China, China Circle, and Chinese economic area. ${ }^{1}$ Expectedly, the exact geographic coverage of these terms depends on the time and context in which they are referred to and differs across users. In this study, we adopt the term Greater China (DaZhongHua in Chinese) despite the potential resentment caused by the similarity between this term and the "Greater East Asia Co-Prosperity Sphere," which was proposed by Japan during World War II.

Greater China is one of the most dynamic regions in the world. Its importance to the global economy has been widely anticipated since the reforms in China began in 1978. ${ }^{2}$ The Greater China's extraordinary growth rates in GDP and trade, especially China, in the last 20 years has dwarfed those of developed economies. While the upsurge of Greater China is attributable to the economic transition in China, it also reflects the success of the export oriented development policy pursued by these economies. The three economies have strong complementary assets - China has rich and low-cost resources, Taiwan has advanced technological know-how and capital, and Hong Kong offers capital, sophisticated financial services, modern management skills, and a well-developed legal system. Consequently, the integration of these economies offers tremendous synergy that propels Greater China to a high growth trajectory.

Since the 1997 financial crisis, the Asian economies have devoted considerable efforts on policy coordination and economic integration. For example, the Early Warning System was established to ensure financial stability in the area. ${ }^{3}$ By the end of 2003 , more than ten bilateral currency swap arrangements were concluded under the provisions

\footnotetext{
$1 \quad$ Harding (1993) provided a succinct account of the origins and various interpretations of the usage of Greater China. Naughton (1997) adopted the term China circle. The term Chinese economic area was used in, for example, Jones, King and Klein (1992).

2 See, for example, Jones, King and Klein (1992), Naughton (1997), World Bank (1997), and Maddison (1998).

3 The Early Warning System assesses the region's financial stability by monitoring the balance of payments, the exchange rate regimes, the levels of foreign borrowing, regional and global capital flows, and the activities of the hedge funds in the ASEAN plus 3 countries. The ASEAN plus 3 countries are Indonesia, Thailand, Singapore, Malaysia, the Philippines, Brunei, Vietnam, Laos, Burma, and Cambodia, plus China, Japan, and South Korea.
} 
of the Chiang Mai Initiative. ${ }^{4}$ These swap arrangements were designed to pool the (dollar) reserves in the region together to defend against hostile speculative attacks. The economies in the region are also active in negotiating regional and bilateral trade agreements. $^{5}$

Besides these trade and policy arrangements, there are other proposals to foster policy coordination and economic integration. These proposals include the establishment of an Asian Monetary Fund, the use of a basket of currencies as an anchor of exchange rates, the adoption of a dollarization policy, and the formation of an Asian currency union. While the notion of a currency union represents a stringent commitment by its member economies, it attracts some interest in the academic circle. For instance, studies including Bayoumi and Mauro (1999), Eichengreen and Bayoumi (1999), Lee, Park and Shin (2002), McKinnon and Schnabl (2003), Ng (2002), and Tsang (2002) found that the Asian economies are not unsuitable for a currency union. However, the differences in the stage of economic development among these economies, the lack of effective institutional arrangements, and the diverse political structures are unfavorable factors for establishing an Asian currency union.

It is hard to deny that there are substantial (economic and political) hurdles of forming a currency union among a large group of Asian economies in the near future. However, the prospect of a few economies to set up a currency union is not too remote. The theme of the current study is to assess the suitability of a currency union for Greater China. Undoubtedly, the interaction between the three Greater China economies is very intense. It is conceivable that these economies will further strengthen their economic ties, which can set the stage for a currency union in the future.

\footnotetext{
$4 \quad$ The Chiang Mai Initiative is a regional financing network introduced by the ASEAN plus 3 countries in May 2002. Technically, the initiative is an expansion of the ASEAN swap arrangement to include the three newcomers. See, for example, Henning (2002) and Bergsten and Park (2002) for discussions on the Chiang Mai Initiative and the construction of a regional financial arrangement in East Asia. For example, the recently concluded free trade agreements in Asian region include the ASEANChina Free Trade agreement, the China-Hong Kong Closer Economic Partnership Agreement, China-Macau free trade pact, and Japan-Singapore free trade agreement. At the same time, JapanASEAN free trade agreement and South Korea-Singapore free trade agreement are under negotiation, and China-Japan-Korea free trade agreement and China-Taiwan free trade agreement have been proposed.
} 
The standard literature considers a few criteria for an optimum currency area. ${ }^{6}$ Business cycle synchronization is one of the criteria used to evaluate the desirability of a currency union. Other criteria include the similarities of trade patterns and levels of economic development, the degree of trade and financial integration, and the mobility of labor markets. In this exercise, we focus on the business cycle synchronization criterion. When business cycles across economies are synchronous, the cost of using a single currency is reduced because there is less need for asymmetric monetary policy responses to common shocks, ceteris paribus. On the other hand, currency union may not be an optimal monetary arrangement when the economies display asynchronous business cycles.

In the literature, various approaches are adopted to assess the contemporaneous correlation of output shocks, which is commonly used to gauge the degree of business cycle synchronization (Bayoumi and Eichengreen, 1994; Lee, Park and Shin, 2002; Alesina, Barro and Tenreyro, 2002). Contemporaneous correlation, however, does not necessarily provide a complete picture. ${ }^{7}$ The effects of shocks on economies crucially depend on the transmission mechanism within and across them. Divergent monetary or exchange rate policies may deem necessary even in the presence of high shock correlation if the transmission mechanisms are sufficiently different among the economies. On the other hand, a relatively low contemporaneous shock correlation does not exclude the possibility that the economies are in similar phases of the business cycle and, hence, does not require different monetary or exchange rate policies. In view of this consideration, we consider a complementary approach and directly examine comovement patterns of output series.

The current exercise assesses both long-run and short-run output synchronization. First, we investigate whether the outputs from the three Greater China economies move together in the long run, which is considered as a minimum requirement for a currency union discussion. Second, we determine whether the three economies share common short-run cyclical business cycles. After all, most monetary policies are devised to

\footnotetext{
$6 \quad$ Mundell (1961) is the seminal study. Some recent reviews of the literature on optimum currency areas are Lafrance and St-Amant (1999) and Bayoumi and Eichengreen (1999).

7 Another difficulty is that output shock correlation results are not robust to different shockestimation methods (Baxter and Stockman, 1989; Harvey and Jaeger 1993; Canova, 1998).
} 
smooth out transitory shocks. If these economies share long-run growth trends and shortrun economic fluctuations, then a single common currency is a reasonable proposition.

To offer further insight to the prospect of establishing a Greater China currency union, we quantify the individual economies' potential output losses of creating one. Since the ideal pre-conditions of a currency union are rarely fulfilled, there is always a cost for an economy to relinquish policy autonomy and join a currency union. Thus, in addition to business cycle synchronization, it is instructive to estimate the individual economies' potential costs of joining a currency union. In this exercise, we use the Ghosh and Wolf (1994) model to characterize the economy and evaluate output losses.

The remainder of the paper is organized as follows. In the next section, we provide some background information on the trade and investment flows between the Greater China economies. Section 3 presents some preliminary analyses on the real per capita GDP data from China, Hong Kong, and Taiwan. Patterns of output comovement are studied in Section 4. The Johansen cointegration test results and links between the long-run and short-run output interactions are reported. In the same section, we also test for the presence of common business cycles. Section 5 evaluates the output costs of forming a currency union. The output losses of Greater China and its individual member economies under different shock-identifying schemes and policy objectives are reported. Some concluding remarks are given in section 6 .

\section{Integration Within Greater China}

For most of the contemporary history, Hong Kong has been China's gateway to the global economy. During the 1960s and 1970s, China acquired a large fraction of its foreign currencies via exporting goods through Hong Kong to the rest of the world. On the other hand, Hong Kong relied on China for its water, food, and other daily necessities. In the last two decades, China and Hong Kong experienced a tremendous increase in economic interactions. For instance, Hong Kong is a main entrepôt and intermediates the lion's share of China's external trade via re-exports and offshore trade. Also, a substantial amount of international capital (in the form of foreign direct investment, equity and bond financing and syndicated loans) financing China's economic expansion is raised via Hong Kong. At the same time, intermediating trade and financial 
flows to China becomes a major form of economic activity in Hong Kong and greatly shapes its economic structure.

Perhaps more surprising to a casual observer, economic links between China and Taiwan have proliferated since the 1990s despite ideological differences and occasional political tensions between these two economies. According to official statistics, China was the largest recipient of Taiwan's overseas investment and Taiwan was China's thirdlargest source of foreign direct investment in 2002. Furthermore, it is widely believed that official statistics under-represent the overall Taiwan economic interest in China. Some analysts estimated that Taiwan's total investment in China is just behind Hong Kong's but ahead of the US's.

The integration process between the three Greater China economies is proceeding more along de facto than de jure lines. Unlike other economic co-operative entities, the integration process within Greater China was not preceded and governed by explicit bilateral or multi-lateral (trade) agreements but fostered by the gradual liberalization policy in China and the relaxation of restrictions in Taiwan on its (economic) interaction with China.The liberalization policy offered opportunities for private sector actors to realize the benefits from combining strengths in these economies, which in turn further facilitated the liberalization process. To some observers, the growing economic integration among the Greater China economies reflects the triumph of economic forces over political constraints.

One way to assess the extent of integration is to look at trade and investment flows. These are the subjects of the next two subsections.

\section{$2.1 \quad$ Trade Relationships}

China's external trade with Hong Kong reflects the evolution of Hong Kong's role as China's gateway to the world economy. In 1991, China's exports to Hong Kong reached US\$32 billion, which accounted for 44.7\% of China exports (Table 1). Of course, Hong Kong re-exported most of its imports from China to the rest of the world. Between 1991 and 2002, the volume of China's exports to Hong Kong increased by US\$26 billion. Despite the huge volume increase, the Hong Kong market only accounted for $18 \%$ of total China's exports in 2002 . 
Table 1.

Trade Between Greater China Economies, in Million US dollar

Panel A: Exports

A.1 Export-Value

Hong Kong/China Taiwan/China Taiwan/Hong Kong

1991

2002

32,138

595

3,967

58,483

6,590

4,438

A.2 Proportion

1991

0.447

0.008

0.040

2002

0.180

0.020

0.022

Panel B: Imports

B. 1 Value

1991

17,543

3,639

9,600

2002

10,788

38,082

14,922

B. 2 Proportion

1991

0.275

0.057

0.096

2002

0.037

0.129

0.071

Panel C: External Trade

C.1: Value

1991

49,681

4,234

13,567

2002

69,271

44,672

19,361

C.2: Proportion

1991

0.366

0.031

0.068

2002

0.112

0.072

0.047

Notes: The Table presents the trade activities between the three Greater China economies in the years 1991 and 2002. The column labelled "XX/YY" gives the data assuming YY is the focal economy; that is, YY's exports to XX, ..., etc. The row label "value' gives the value of trade activities and "Proportion" gives the ratio of the trade value between XX and YY to the total trade value of YY. "External Trade" refers to the sum of exports and imports.

There are two reasons for the Hong Kong's decreasing market share. First, in the process of intensifying its open door policy, China has expanded its capacity to export directly by establishing various direct trade links with the rest of the world and developing its own port and harbor facilities. These changes occurred at a fast pace in the 1990s. Thus, China's reliance on Hong Kong to re-export its merchandise to the rest of the world has, thus, been mitigated.

Another reason is the change in the manner in which Chinese trade data are recorded. ${ }^{8}$ Before 1992 , the Chinese official statistics greatly distorted its trading

$8 \quad$ See General Agreement on Tariffs and Trade (1994), International Monetary Fund (1995), and an un-circulated International Monetary Fund internal document. 
relationships with its trading partners because there was no official record of final destinations of Chinese goods and merchandise that were exported through Hong Kong. This problem got international attention only when countries traded more with China and required information to accurately assess their trade positions with China. Starting from 1992, China began to report its trade statistics according to the final destination of exports. China, with the change in reporting method, recorded a big drop in trade with Hong Kong - its major entrepôt in 1993. Indeed, if one excludes the 1993 figure from the 1991-2002 sample, the average annual growth rate of China's exports to Hong Kong increased from $9.23 \%$ to $13.82 \%$.

The evolution of China's imports from and total trade with Hong Kong is similar to that of China's exports. While China has created an extensive international trade network in the wake of the open door policy, Hong Kong still plays an important role in China trade. Given the Closer Economic Partnership Arrangement signed by China and Hong Kong in 2003 and the proposal on developing the Pearl River Delta region, one can only anticipate further integration between China and Hong Kong.

Strictly speaking, China and Taiwan do not have direct trade. Taiwan's official stance was to prohibit any trade with China until the early 1990s. Since then, Taiwan has allowed indirect trade with China via a third territory (mainly via Hong Kong). In 1999, the rule was further loosened and Taiwan merchandise can transit via the third territory without unloading before shipping to China. Even without direct trade, the trade volume between these two economies has grown two times or ten times, depending on the data sources, in the 1990s. ${ }^{9,10}$ According to the Chinese statistics, the trade between China and Taiwan has enjoyed a remarkable growth - an average annual growth rate of $22 \%$, since1991. Despite the phenomenal growth, Taiwan's total external trade (exports plus

9 Because of trade restrictions and other political reasons, the official data from China, Taiwan and Hong Kong on trade between China and Taiwan are usually perceived to be incomplete. For instance, the value (in billions of US dollars) of total trade between China and Taiwan was 5.8 in 1991 and 10.5 in 2001, according to Hong Kong customs (re-export) data, 0.6 in 1991 and 10.6 in 2001 according to Taiwanese customs data, and 4.2 in 1991 and 32.4 in 2001 according to Chinese customs data.

10 Apparently, steps have been taken to provide accurate China trade data. For instance, Taiwan authorities, despite its official ban on direct trade with China, have been asking exporters to report the final destination of their shipments, even if it is China. 
imports) with China was still less than Hong Kong's though Taiwan exported more to China than Hong Kong did in 2002.

In the early 1990s Taiwan imported only a minute amount of goods from China. The low level of imports reflected restrictions imposed by Taiwanese authorities (justified by security reasons) rather than the anaemic demand for Chinese goods in Taiwan. With relatively small initial exports to Taiwan, China has maintained a considerable trade deficit with Taiwan throughout the 1990s even though the growth rate of its exports to Taiwan was higher than that of imports. According to the 2002 Chinese figures, its trade deficit with Taiwan stood at 31.5 billion US dollars, which is comparable to the overall trade surplus recorded for Taiwan in the same year. ${ }^{11}$

Relative to China, the trade growth between Hong Kong and Taiwan is quite slow. The Hong Kong's export to, import from, and total external trade with Taiwan registered only single-digit growth rates in the 1990s.

The trade figures indicated that China has significantly intensified its trade relationship with Hong Kong and Taiwan. A smaller improvement was the trade relationship between Hong Kong and Taiwan. The trade volume between these three economies was quite non-trivial in 2002, the total external trade between the three Greater China economies accounted for $1 \%$ of world trade.

\subsection{Foreign Direct Investment}

There is a technical issue on classifying investment from Hong Kong and Taiwan in China. Should Hong Kong's investment in China be labeled as foreign investment? Even before July 1997 - when Hong Kong was officially under China's jurisdiction, China's official position was that Hong Kong is an integral part of China. Similarly, China considers Taiwan its sovereign territory and not an independent political entity. If one strictly adheres to this stance, then Hong Kong's and Taiwan's investment is not “foreign” investment in China! In practice, however, Hong Kong's and Taiwan's investment is treated as foreign investment in China and enjoys substantial preferential treatment. Thus, we follow the common practice and label Hong Kong's and Taiwan's 
Table 2. China's Foreign Direct Investment from Hong Kong and Taiwan, in Million US Dollar

\begin{tabular}{lccc}
\hline & & Hong Kong & Taiwan \\
\hline A. Value & 1991 & 2405 & 466 \\
& 2002 & 17861 & 3971 \\
B. Proportion & & & \\
& 1991 & 0.55 & 0.11 \\
& 2002 & 0.34 & 0.08 \\
\hline
\end{tabular}

Notes: Hong Kong's and Taiwan's investments in China during the years 1991 and 2002 are presented. "Value" gives the UD dollar amount of investment and "Proportion" gives the ratio of the investment amount to China's total foreign direct investment.

investment in China as foreign investment in China.

Hong Kong and Taiwan provide a large proportion of foreign direct investment to China (Table 2). The substantial presence of Hong Kong in these investment data is a testament to its role as a main platform for investment in China. The role was enhanced by China's policies in her early phase of the reform program that aimed at attracting investment from Hong Kong, Macao, and Taiwan. Clearly, Hong Kong's domestic resources were not enough to account for the reported capital flow. In addition to its domestic sources, it is believed that Hong Kong investment in China was funded by a) capital originating in China that was invested back in China via Hong Kong entities in order to enjoy the preferential treatment not available to China's own local capital, b) Taiwan's investment in China that was channeled through Hong Kong in order to circumvent restrictions imposed by the Taiwanese authorities, and c) multinational corporations that used Hong Kong as the bridgehead to enter the Chinese market.

Hong Kong, one of the renowned international finance centers, has a few advantageous features to facilitate capital flow to China. These features include a wellestablished legal system, a business environment similar to other developed countries, an efficient financial sector, the kinship network, and expertise in China economy. The ability to perform the role of middleman to channel foreign capital into China has reinforced Hong Kong's status as an international finance center. anticipated that there will be an increase of Chinese goods and merchandise in Taiwan and 
Both Chinese and Taiwanese data are perceived to under-report Taiwan's investment interest in China. The official figures rank Taiwan's investment in China behind Hong Kong, the US, and Japan. Nonetheless, the guesstimate usually puts Taiwan the second largest source only after Hong Kong. It is believed that a substantial amount of Taiwan's interest in China is invested through, in addition to Hong Kong, the Virgin Islands. The investment flow from the Virgin Islands to China has been quite astonishing in the last ten years. In 1992, China received US\$4 million foreign direct investment from the Virgin Islands and in 2002 the investment flow reached US\$6.1 billion. ${ }^{12}$

Undeniably, the capital from Hong Kong and Taiwan plays an important role in China's recent economic success. The two economies provided the lion's share of foreign capital to China - a total of $66 \%$ in 1991 and of $42 \%$ in 2002 . It is worth noting that both Hong Kong and Taiwan are not a major supplier in the world capital market. Their investment commitments in China are underpinned by China's policy and the kinship network that spreads across the Greater China region. These investment opportunities allow the three Greater China economies to effectuate their complementary resources, foster their economic growth, and elevate Greater China to the world economic stage.

\section{Preliminary analyses}

As revealed in the preceding section, the three Greater China economies display a high level of economic integration. The extensive interaction between these economies provides a good foundation for advancing integration to a higher level. In this section, we present some basic properties of the output data.

Quarterly China, Hong Kong, and Taiwan real per capita GDP data are considered. The sample period is 1994:I to 2002:IV. The sample period is mainly dictated by data availability and the liberalization process in China. Although China started its economic reforms in 1978, she had a substantially controlled economy before the early 1990s. Extending the data series backward would not yield useful information relevant to our exercise. The data are retrieved from the CEIC and International Financial Statistics databases and are seasonally adjusted using the Census Bureau's X12 method. For 
brevity, the quarterly real per capita GDP data are referred to as GDP or output data henceforth.

As a preliminary analysis, the augmented Dickey-Fuller (ADF) test is used to test for a unit root in individual output series. The ADF test is based on the regression equation,

$$
\Delta X_{i t}=c_{i}+\tau_{i} t+\delta_{i} X_{i t-1}+\sum_{j=1}^{p} \alpha_{i j} \Delta X_{i t-j}+\varepsilon_{i t}
$$

Table 3. Unit Root Test Results

\begin{tabular}{rccc}
\hline & China & Hong Kong & Taiwan \\
\hline A. Levels & & & \\
Test Statistic & -2.71 & -2.21 & -1.45 \\
Q Lags & 1 & 4 & 1 \\
Q-Statistics: $Q(4)$ & 7.131 & 0.526 & 1.744 \\
& $(0.129)$ & $(0.971)$ & $(0.783)$ \\
B. First Differences & 10.357 & 11.411 & 3.392 \\
Test Statistic & $(0.241)$ & $(0.179)$ & $(0.859)$ \\
$\#$ of Lags & $-8.31 * *$ & & $-4.08 * *$ \\
Q-Statistic: $Q(4)$ & 1 & $-3.95 * *$ & 0 \\
& 6.074 & 3 & 1.439 \\
$Q(8)$ & $(0.194)$ & 0.387 & $(0.837)$ \\
& 6.339 & $(0.984)$ & 2.827 \\
& $(0.609)$ & 9.786 & $(0.280)$ \\
& & &
\end{tabular}

Note: The results of applying augmented Dickey-Fuller tests to the China, Hong Kong and Taiwan real per capita GDP data are reported. Lags are selected to make the serial correlation in residuals insignificant. The BoxLjung statistics based on the first four and first eight serial correlations of the estimated residuals are given under the heading " $\mathrm{Q}(4)$ and $\mathrm{Q}(8)$ " and their p-values are given in parentheses underneath. "**” indicates significance at the 5\% level (Cheung and Lai, 1995). 
where $X_{i t}$ is the economy i's GDP at time $t$, expressed in logs, for $i=$ China, Hong Kong, and Taiwan, $\Delta$ is the first-difference operator, $c_{i}$ and $t$ are, respectively, an intercept and time trend, and $\varepsilon_{i t}$ is the associated error term. Under the unit-root hypothesis, $\delta_{i}=0$. The lag parameter $(p)$ is chosen to eliminate serial correlation in the estimated residuals.

The ADF test results are reported in Panel A of Table 3. For all three GDP series, the test statistics do not reject the unit root hypothesis. Panel B contains the results from first-differences of GDP data. In this case, only a constant term was included in the ADF regression equation. The first-differenced GDP data reject the unit root null hypothesis; that is, the first-differenced data are I $(0)$. As indicated by the Q-statistics, the lag specifications used to conduct these tests adequately capture the intertemporal GDP dynamics. These results strongly suggest that the GDP series are I(1) processes.

\section{Long-Run and Short-Run Output Variations}

Since the GDP date are I(1), each series has a stochastic trend. Thus, we employ the Johansen cointegration procedure to test whether the three Greater China economies' GDP series share any common stochastic trend; that is, whether they are cointegrated. In addition to identifying common long-run comovement, the cointegration results help specify the appropriate model to study short-run output interactions and cycles.

\subsection{Common Stochastic Trend}

A currency union has implications for interactions between its member economies that go beyond bilateral relationships. In contrast with the usual bilateral setting embedded in most, if not all, recent studies on currency unions, the cointegration model is a multivariate framework that incorporates interactions between all data series in assessing output movement patterns. Further, the cointegration model provides a coherent structure to study output interactions in both the long run and short run. Specifically, we can infer whether the national output series move together in the long run, how deviations from the long-run relationship affect short-run output movements, and how outputs interact in the short run. The structure is flexible enough to accommodate various types of data dynamics in the analysis. 
The Johansen cointegration test procedure is conducted as follows. Suppose $\mathbf{X}_{\mathbf{t}}$ is a nx1 vector containing individual GDP series $X_{i t}$ 's and has a ( $\left.\mathrm{p}+1\right)$-th order autoregressive representation:

$$
\mathbf{X}_{t}=\mu+\sum_{i=1}^{p+1} \gamma_{i} \mathbf{X}_{t-i}+\varepsilon_{t},
$$

where $\mu$ is the intercept term, and $\varepsilon_{t}$ is the innovation vector. To test whether the elements in $\mathbf{X}_{\mathbf{t}}$ are cointegrated, the Johansen procedure tests for significant canonical correlations between $\Delta \mathbf{X}_{t}$ and $\mathbf{X}_{t-p-1}$, after adjusting for all intervening lags. Johansen (1991) and Johansen and Juselius (1990), for example, give a detailed description of the test.

The cointegration test results are reported in Table 4. Again, the lag parameter (p) is selected to obtain insignificant serial correlation in the residuals. According to both the maximum eigenvalue and trace statistics, the null hypothesis of no cointegration is rejected in favor of the presence of one cointegrating vector. Further, there is no evidence that there exists more than one cointegrating vector. These results suggest that the output series are cointegrated. That is, the stochastic trends that drive the individual output series to wander randomly over time are common to the three Greater China economies such that the output series have synchronous long-term movements. The empirical long-run relationship is given by the cointegrating vector.

Table 4. Cointegration Test Results

\begin{tabular}{lcc}
\hline $\mathrm{H}(0)$ & Max. Eigen. Statistic & Trace Statistic \\
\hline $\mathrm{r}<=2$ & 0.07 & 0.07 \\
$\mathrm{r}<=1$ & 10.80 & 10.87 \\
$\mathrm{r}<=0$ & $22.60^{* *}$ & $33.40^{* *}$ \\
\hline
\end{tabular}

Note: The Johansen maximum eigenvalue test and trace test statistics are reported, respectively, under the headings "Max Eigen. Statistic" and "Trace Statistic." The 5\% level of significance is indicated by "***" (Cheung and Lai, 1993). The lag parameter is 2 . The estimated cointegrating vector is $(1,-1.66-1.31)$ with the China coefficient normalized to 1 . The test statistics for the cointegrating coefficients are 14.88 (China), 20.71 (Hong Kong), and 12.17 (Taiwan); that is, each element of the cointegrating vector is significant.

The cointegration of output data may be viewed as a necessary condition for establishing a currency union. If the output series are not cointegrated, they drift apart in the long run. In this case, it is difficult to effectively manage the three economies using a 
common monetary policy and a common currency. Thus, the cointegration result, which implies the national output data are synchronous in the long run, is supportive of the concept of a currency union between China, Hong Kong, and Taiwan.

\subsection{Short-Run Interaction}

Since the three GDP series are cointegrated, a vector error correction model (VECM), instead of a vector autoregressive model, is the appropriate framework to study their short-run interactions. The VECM is given by

$$
\Delta \mathbf{X}_{t}=\mu+\sum_{i=1}^{p} \Gamma_{i} \Delta \mathbf{X}_{t-i}+\alpha Z_{t-p-1}+\varepsilon_{t}
$$

where $Z_{t-p-1}$ is the error correction term given by $\hat{\beta}^{\prime} \mathbf{X}_{t-p-1}$ and $\hat{\beta}$ is the estimated cointegrating vector. The VECM results are presented in Table 5. The Q-statistics affirm that the selected VECM models adequately capture the data dynamics and the resulting disturbance terms display no statistically significant serial correlation.

The adjustment of output growth $\Delta \mathbf{X}_{t}$ to deviations from the empirical long-run relationship is captured by the $\alpha$ coefficient vector. The error correction term is significant in only the Kong Kong and Taiwan, but not the China, equations. That is, Hong Kong and Taiwan respond to deviations from the empirical long-run relationship, which is given by the cointegrating vector. On the other hand, China does not react to the deviation as the error correction term has a small and insignificant coefficient estimate. One interpretation of these $\alpha$ coefficient estimates is that China GDP causes both Hong Kong and Taiwan outputs in the long run, but not vice versa (Granger and Lin, 1995). The result seems reasonable. Since the 1980s, Hong Kong and Taiwan have invested a large amount of capital and relocated a large number of manufacturing facilities to China and, at the same time, China has become a significant export market for these two economies. In addition, the China economy is much larger than the Hong Kong and Taiwan ones. These factors have created complex economic linkages between the three Greater China economies and the reliance of the two small economies to the large one.

The short-run dynamics are described by the $\Gamma_{i}$ coefficient matrices, which relate output growth $\left(\Delta \mathbf{X}_{t}\right)$ to short-term variation in lagged output movements. The three GDP growth equations display different responses to lagged GDP growth. The China 
Table 5. China/Hong Kong/Taiwan Vector Error Correction Model

\begin{tabular}{lccc}
\hline & China & Hong Kong & Taiwan \\
\hline \multirow{2}{*}{ ECT } & & & \\
& -0.003 & $0.162^{* *}$ & $0.141^{* *}$ \\
CH GDPG(-1) & $(-0.118)$ & $(3.510)$ & $(3.645)$ \\
& $-0.317^{* *}$ & -0.171 & -0.094 \\
CH GDPG(-2) & $(-2.025)$ & $(-0.662)$ & $(-0.434)$ \\
& $-0.410^{* *}$ & $0.400^{*}$ & 0.252 \\
HK GDPG(-1) & $(-2.987)$ & $(1.766)$ & $(1.333)$ \\
HK GDPG(-2) & -0.031 & $0.438^{* *}$ & -0.202 \\
& $(-0.269)$ & $(2.334)$ & $(-1.288)$ \\
TW GDPG(-1) & 0.026 & 0.031 & 0.127 \\
TW GDPG(-2) & $(0.236)$ & $(0.169)$ & $(0.837)$ \\
& 0.099 & $-0.449^{* *}$ & 0.041 \\
Constant & $(0.755)$ & $(-2.063)$ & $(0.223)$ \\
& 0.101 & -0.125 & -0.143 \\
& $(0.737)$ & $(-0.548)$ & $(-0.751)$ \\
Adjusted $-R^{2}$ & -0.055 & $4.128^{* *}$ & $3.593 * *$ \\
& $(-0.078)$ & $(3.509)$ & $(3.648)$ \\
Q(4) & & & \\
& 0.162 & 0.489 & 0.299 \\
Q(8) & & & \\
& 6.631 & 7.053 & $(0.732)$ \\
& $(0.157)$ & $(0.133)$ & 8.890 \\
& 7.499 & 9.625 & $(0.352)$ \\
\hline
\end{tabular}

Note: The estimates of the vector error correction model for China (CH), Hong Kong (HK), and Taiwan (TW) are presented. GDPG refers to GDP growth. Robust t-statistics are given in parentheses below the parameter estimates. “**” and "*” indicate significant at the 5\% and $10 \%$ level, respectively. ECT is the error correction term. $\mathrm{Q}(\mathrm{p})$ is the $\mathrm{Q}$-statistic calculated from the first $\mathrm{p}$ sample autocorrelations with the associated $\mathrm{p}$-value given in parentheses underneath.

economy, which is the largest among the three, depends only on its own lagged growth rates. The Hong Kong economy, on the other hand, responds to growth rates in all the three economies. The dependence of Hong Kong on the other two economies corroborates with its size and openness - Hong Kong is the smallest and the most open economy in the group. ${ }^{13}$ No lagged GDP growth variable is significant in the Taiwan equation. Even though the economic links between China and Taiwan have increased 
quite substantially, our analysis reveals a significant China effect on Taiwanese growth rate only via the error correction term but not the lagged China GDP growth.

\subsection{Synchronized and Non-Synchronized Short-Run Cycles}

In addition to long-run trends, business cycle synchronization is a key element of designing a currency union arrangement. A common currency and a common monetary policy can be quite ineffective in managing and fine-tuning the economic activity in a currency union if shocks are asymmetric and national business cycles are asynchronous. On the other hand, a common monetary policy can be desirable when business cycles are synchronous across economies because there is less need for asymmetric monetary policy responses. In reality, the commonality of (short-run) cyclical movements is a crucial and practical aspect of policy coordination considerations.

Since the cycle of an output growth series is often represented by its serial correlation, the presence of common serial correlation patterns is taken as evidence of common cyclical variations in business cycles. In this exercise, the common feature test (Engle and Kozicki, 1993; Vahid and Engle, 1993) is used to detect common serial correlations. The test is based on sample canonical correlations between $\Delta \mathbf{X}_{t}$ and $\mathbf{W}(p) \equiv\left(\Delta \mathbf{X}_{t-1}^{\prime}, \ldots, \Delta \mathbf{X}_{t-p}^{\prime}, Z_{t-1}\right)$ and determines the number of co-feature vectors. If there is common serial correlation, then there is a linear combination of the components of $\Delta \mathbf{X}_{t}$, defined by a co-feature vector, displays no serial correlation. The test statistic for the null hypothesis that there are at least $s$ co-feature vectors is given by

$$
C(p, s)=-(T-p-1) \sum_{j=1}^{s} \ln \left(1-\lambda_{j}\right),
$$

where $\lambda_{j}$ is the $\mathrm{j}$-th smallest squared canonical correlations between $\Delta \mathbf{X}_{t}$ and $\mathbf{W}(p)$. The dimension (rank) of the co-feature space is the number of statistically zero squared canonical correlations. Under the null hypothesis, the statistic $C(p, s)$ has a $\chi^{2}$-distribution with $s^{2}+s n p+s r-s n$ degrees of freedom. 194 for Hong Kong. The levels of openness measured by the trade to GDP ratio are 2.54 for Hong Kong, 0.83 for Taiwan, and 0.48 for China at 2002. 
The presence of a common feature requires the component series to respond to stochastic shocks simultaneously with a similar pattern. If the component series have different initial responses to stochastic shocks, there will be no common feature. However, because of economy-specific factors including institutional structures and capital/labor input, the Greater China economies can have dis-similar initial responses to shocks, and shocks propagate through economies at uneven speeds. Despite different initial responses, these economies can react fully and symmetrically to the shock in later periods. This type of "non-synchronized" cycles might be difficult to detect using the common feature test statistic (4), which is designed to detect synchronized cycles. Vahid and Engle (1997) devise the codependence test to test for the presence of common but non-synchronized business cycles. Specifically, the test statistic for the null hypothesis that there are at least $s$ codependence vectors after the $\mathrm{k}$-th period is

$$
C(k, p, s)=-(T-p-1) \sum_{j=1}^{S} \ln \left\{1-\left[\lambda_{j}(k) / d_{j}(k)\right]\right\},
$$

where $\lambda_{\mathrm{n}}(k) \geq \ldots \geq \lambda_{1}(k)$ are the squared canonical correlations between $\Delta \mathbf{X}_{t}$ and $\mathbf{W}(\mathrm{k}, \mathrm{p})$ $\equiv\left(\Delta \mathbf{X}_{t-k-1}^{\prime}, \ldots, \Delta \mathbf{X}_{t-k-p}^{\prime}, Z_{t-1}\right)$, and $d_{j}(k)$ is given by

$$
d_{j}(k)=1, \quad \text { for } k=0,
$$

and

$$
d_{j}(k)=1+2 \sum_{v=1}^{k} \rho_{v}\left(\alpha^{\prime} \Delta X_{t}\right) \rho_{v}\left(\gamma^{\prime} W(k, p)\right) \text { for } k \geq 1
$$

where $\rho_{v}\left(y_{t}\right)$ is the sample autocorrelation of $y_{\mathrm{t}}$ at $v$-th lag, $\alpha$ and $\gamma$ are the canonical variates corresponding to $\lambda_{j}(k)$. Note that when $k=0$, the codependence test statistic $C(k, p, s)$ is reduced to the common feature test statistic; that is, $C(0, p, s) \equiv C(p, s)$. Under the null hypothesis, the statistic $C(k, p, s)$ has a $\chi^{2}$-distribution with $s^{2}+s n p+s r-$ sn degrees of freedom.

The common feature and codependence test results are reported in Table 6. In Panel A, the hypothesis of one co-feature vector is not rejected but both the hypotheses of two and three co-feature vectors are rejected. That is, the Greater China GDP series share synchronized cyclical movements and there exists a linear combination of these output growth series that displays no significant serial correlation. Thus, in addition to common long-run trends, the three Greater China economies share common business cycles. 
Table 6. Synchronized and Non-Synchronized Cycles

\begin{tabular}{|c|c|c|c|c|c|}
\hline \multirow[b]{2}{*}{ Null } & \multicolumn{2}{|c|}{ Common Feature Test } & \multicolumn{2}{|c|}{ Co-Dependence Test } & \multirow[b]{2}{*}{$\begin{array}{l}\text { Deg of } \\
\text { Freedom }\end{array}$} \\
\hline & $\begin{array}{c}\text { Squared } \\
\text { Canonical } \\
\text { Correlation }\end{array}$ & $\frac{\text { Statistic }}{\underline{C}(p, s)}$ & $\begin{array}{c}\text { Squared } \\
\text { Canonical } \\
\text { Correlation }\end{array}$ & $\frac{\text { Statistic }}{\mathrm{C}(p, k, s)}$ & \\
\hline $\begin{array}{l}S= \\
1\end{array}$ & 0.166 & 5.472 & 0.104 & 2.363 & 5 \\
\hline $\begin{array}{l}S= \\
2\end{array}$ & 0.417 & $21.659 * *$ & 0.188 & 8.140 & 12 \\
\hline $\begin{array}{l}S= \\
3\end{array}$ & 0.909 & $93.807 * *$ & 0.917 & $96.912 * *$ & 21 \\
\hline
\end{tabular}

Note: The common feature and codependence test results are reported. "s" gives the number of common feature or codependence vectors. Under the null hypothesis, the common feature test statistic $C(p, s)$ and codependence test statistic $C(p, k, s)$ have an asymptotic $\chi^{2}$ distribution with $s^{2}+s n p+s r-s n$ degrees of freedom, where, in this exercise, $n=3, p=2, k=1$, and $r=1$. “**” indicates significance at the $5 \%$ level.

The co-dependence test results in Panel B are based on $\mathrm{k}=1$ and are indicative of the presence of two co-dependence vectors. In addition to synchronized business cycles, these Greater China economies also share non-synchronized business cycles. Since the co-dependence test is a generalized version of the common feature test, the synchronized cyclical component detected by the common feature test will also be detected by the codependence test. It is appropriate to interpret that one of the two co-dependence vectors is the co-feature vector reported in Panel A. Overall, the results indicate that the Greater China economies share common business cycles - some are synchronized, and some are non-synchronized and display dis-similar patterns in the first quarter of the cycle.

\section{Possible Output Losses}

There are both benefits and costs of forming a currency union. It is conceived that benefits come at the microeconomic level and derive from, for example, gains in economic efficiency, reduction in transaction costs (for both business and consumers), elimination of foreign exchange uncertainty, and improved cross-border price transparency. The typical costs are related to macroeconomic management. Joining a 
currency union implies the monetary authorities have to relinquish policy autonomy and lose the capacity to fine-tune the economy. When shocks to individual economies are not identical, a common monetary policy has limited scope to stabilize and offset effects of shocks on all its member economies. Thus, the inability of fine-tuning is a potential macro cost. Even though the three Greater China economies are quite well integrated, these economies are not likely to meet all the ideal pre-conditions of a currency union. Thus, it is instructive to investigate the potential cost of joining a currency union. ${ }^{14}$

\subsection{The Model}

Intuitively, the cost of giving up monetary policy autonomy is low if the union's common monetary policy is effective in managing shocks to its member economies. The common monetary policy can be ineffective and the costs can be high if shocks to the economies are different and there are significant (nominal) rigidities. While it is not easy to evaluate these costs, we use the Ghosh and Wolf (1994) model to illustrate the possible consequences of relinquishing monetary policy autonomy. Specifically, the model assumes nominal wage rigidity to establish the benefits of autonomous monetary policy. Before joining a currency union, individual economies use their own monetary policies to fine-tune their economies in the presence of adverse shocks to achieve full employment. Under a currency union arrangement, however, a common monetary policy is used to combat a union-wise shock, which is a function of shocks to its member economies. Since the union-wise shock is not necessarily the same as individual shocks, the adoption of a common policy does not allow every member economy to achieve full employment simultaneously and, hence, induces the output cost of joining a currency union.

Consider the scenario before joining a currency union. Let an economy's output is given by

$$
Q_{t}=e^{\theta_{t}} l_{t}^{\alpha},
$$

where $\theta_{t}$ is a productivity shock, $l_{t}$ is labor employed in period $\mathrm{t}$, and $0<\alpha<1$ is the labor share. The real wage is equal to the marginal product of labor. The nominal wage rate, $w_{t}$, is downward sticky and is based on information available at $\mathrm{t}-1$,

14 Evaluating the benefits of forming a currency union is an important and involving task that is beyond the scope of the current exercise. 


$$
\log \left(w_{t}\right)=\log \left(E_{t-1} p_{t}\right)+\log (\alpha)+E_{t-1} \theta_{t}+(\alpha-1) \log (\bar{l})
$$

where $p_{t}$ is the price level, and $E_{t-1}$ is the expectations operator based on information available at time t-1. It is assumed that the wage is set (given the expected price and expected productivity shock) to clear the labor market; thus, $\bar{l}$ is the equilibrium employment level. Since the nominal wage is only rigid downward, the wage rate adjusts to clear the market if the unexpected productivity shock $\varepsilon_{t}\left(\cong \theta_{t}-E_{t-1} \theta_{t}\right)$ is positive. However, if the unexpected productivity shock $\varepsilon_{t}$ is negative, the wage rate does not move down and the actual ex post labor demand $\left(l_{t}\right)$ is given by

$$
\log \left(p_{t}\right)+\theta_{t}+(\alpha-1) \log \left(l_{t}\right)=\log \left(w_{t}\right) .
$$

Note that $l_{t}$ does not represent the equilibrium employment level. If the economy is not in a currency union, monetary policies can be used to offset the adverse shock and restore labor market equilibrium by setting the price at the level

$$
\log \left(p_{t}\right)-\log \left(E_{t-1} p_{t}\right)=-\varepsilon_{t} .
$$

In this case,

$$
\begin{aligned}
\log \left(p_{t}\right)+\theta_{t}+(\alpha-1) \log (\bar{l}) & =\log \left(w_{t}\right) \\
& =\log \left(E_{t-1} p_{t}\right)+E_{t-1} \theta_{t}+(\alpha-1) \log (\bar{l}) .
\end{aligned}
$$

Now suppose the economy forms a currency union with another economy. Let the productivity shock to the currency union be $\varepsilon_{t}^{c}$, which is a combination of shocks to the two member countries. Further, assume the currency union's monetary authorities pursue a stabilization policy similar to (9) and set the union's price level $\left(p_{t}^{c}\right)$ according to

$$
\log \left(p_{t}^{c}\right)-\log \left(E_{t-1} p_{t}^{c}\right)=-\varepsilon_{t}^{c}
$$

When $\varepsilon_{t}<\varepsilon_{t}^{c}$, the policy (11) does not yield full employment for the economy under consideration. From (6), (8) and (11), the economy's output loss, in percentage term, is given by

$$
L_{t}=1-\exp \left[\left(\varepsilon_{t}-\varepsilon_{t}^{c}\right) \alpha /(1-\alpha)\right] .
$$

Equation (12) summarizes the three factors that determine the output loss of joining a currency union: the shock to the economy $\varepsilon_{t}$, the shock to the currency union $\varepsilon_{t}^{c}$, and 
the labor share $\alpha$. See Ghosh and Wolf (1994) for a detailed discussion of the model, interpretations, and caveats.

\subsection{The Estimated Losses}

Equation (12), which offers a good initial approximation for quantifying the costs of joining a currency union, is used to assess the potential output losses. We calculate the output losses for each of the three Greater China economies and for Greater China as a whole. To accommodate various possible scenarios, the output losses are calculated from the following configurations: a) the labor share ranges from 0.3 to $0.7, b$ ) two ways to characterize the currency union-wide shock - one is the GDP-weighted average of individual economies' output shocks and the other is the simple average of individual economies' output shocks, and c) three approaches to derive output shocks - one based on the VECM, one based on the Hodrick-Prescott (HP) filter, and one based on the Blanchard-Quah (BQ) (1989) method.

Table 7 presents the estimated average percentage output losses. The estimates based on the assumption that the currency union shock is the GDP-weighted average of individual economies' shocks are given in columns 3 to 5 and those based on the assumption that the currency union shock is the simple average of individual economies' shocks are given in columns 6 to 8 . A few observations are in order.

First, the estimates illustrate the role of labor share quite clearly. As indicated by equation (12), a larger labor share implies a larger percentage of output loss, which is a consequence of the nominal wage rigidity assumption. Indeed, when the labor share increases, the estimated output loss increases quite significantly. For instance, China's percentage output loss estimate increases more than fivefold where the labor share parameter increases from 0.3 to 0.7 . Similar changes in output losses are found in other economies.

Second, the percentage output loss estimate appears quite sensitive to the method used to extract the shock. Under both currency union shock specifications, the HP filter yields the highest output loss estimates and the BQ method delivers the lowest estimates. The results highlight the importance of the shock-estimation method in evaluating the output loss of joining a currency union. The sensitivity of loss estimates to shock 
Table 7. Estimated Average Output Losses in Percentages

\begin{tabular}{|c|c|c|c|c|c|c|c|}
\hline & & \multicolumn{3}{|c|}{$\begin{array}{l}\text { GDP-Weighted Average } \\
\text { of Shocks }\end{array}$} & \multicolumn{3}{|c|}{$\begin{array}{c}\text { Simple Average of } \\
\text { Shocks }\end{array}$} \\
\hline & & VECM & $\underline{\text { Filter }}$ & $\underline{\mathrm{BQ}}$ & VECM & $\underline{\text { Filter }}$ & BQ \\
\hline \multirow[t]{4}{*}{$\alpha=0.7$} & China & 0.140 & 0.280 & 0.074 & 0.209 & 0.408 & 0.150 \\
\hline & Hong Kong & 0.617 & 1.712 & 0.471 & 0.542 & 1.224 & 0.382 \\
\hline & Taiwan & 0.505 & 0.868 & 0.043 & 0.445 & 0.517 & 0.066 \\
\hline & $\begin{array}{l}\text { Greater } \\
\text { China }\end{array}$ & 0.272 & 0.563 & 0.122 & 0.301 & 0.521 & 0.169 \\
\hline \multirow[t]{4}{*}{$\alpha=0.6$} & China & 0.090 & 0.181 & 0.048 & 0.134 & 0.263 & 0.096 \\
\hline & Hong Kong & 0.399 & 1.111 & 0.305 & 0.350 & 0.792 & 0.247 \\
\hline & Taiwan & 0.326 & 0.563 & 0.028 & 0.287 & 0.334 & 0.043 \\
\hline & $\begin{array}{l}\text { Greater } \\
\text { China }\end{array}$ & 0.175 & 0.365 & 0.079 & 0.194 & 0.337 & 0.109 \\
\hline \multirow[t]{4}{*}{$\alpha=0.5$} & China & 0.060 & 0.121 & 0.032 & 0.090 & 0.176 & 0.064 \\
\hline & Hong Kong & 0.267 & 0.745 & 0.204 & 0.234 & 0.530 & 0.165 \\
\hline & Taiwan & 0.218 & 0.377 & 0.019 & 0.192 & 0.224 & 0.029 \\
\hline & $\begin{array}{l}\text { Greater } \\
\text { China }\end{array}$ & 0.117 & 0.244 & 0.053 & 0.130 & 0.225 & 0.073 \\
\hline \multirow[t]{4}{*}{$\alpha=0.4$} & China & 0.040 & 0.080 & 0.021 & 0.060 & 0.117 & 0.043 \\
\hline & Hong Kong & 0.178 & 0.498 & 0.137 & 0.156 & 0.354 & 0.110 \\
\hline & Taiwan & 0.146 & 0.252 & 0.012 & 0.128 & 0.149 & 0.019 \\
\hline & Greater & 0.078 & 0.163 & 0.035 & 0.087 & 0.150 & 0.049 \\
\hline \multirow[t]{4}{*}{$\alpha=0.3$} & China & 0.026 & 0.052 & 0.014 & 0.039 & 0.076 & 0.027 \\
\hline & Hong Kong & 0.115 & 0.321 & 0.088 & 0.100 & 0.228 & 0.071 \\
\hline & Taiwan & 0.094 & 0.163 & 0.008 & 0.082 & 0.096 & 0.012 \\
\hline & $\begin{array}{l}\text { Greater } \\
\text { China }\end{array}$ & 0.050 & 0.105 & 0.023 & 0.056 & 0.097 & 0.031 \\
\hline
\end{tabular}

Note: "GDP-Weighted Average of Shocks" and "Simple Average of Shocks" give the estimated average percentage output losses based on the assumptions that the currency union shock is given by the GDPweighted average and by the simple average of shocks to its member countries. The row "Greater China" gives the losses for the three economies as a group. Results based on shocks estimated from the vector error correction model, the HP Filter, and the Blanchard-Quah method are, respectively, given under "VECM," "HP Filter," "BQ." " $\alpha$ " is the labor share parameter.

extraction method is comparable to the sensitivity of the estimated benefits from free trade derived from different specifications reported in, for example, Brown et al. (2002) and Scollay and Gilbert (2001). 
Third, the rankings of output losses across the two specifications of currency union shocks are quite similar. For instance, Hong Kong has the highest percentage output loss estimates in all the cases under consideration. Its percentage output loss ranges from $0.071 \%$ (simple average, $\alpha=0.3, \mathrm{BQ}$ ) to $1.712 \%$ (weighted-average, $\alpha=$ $0.7, \mathrm{HP})$. China, on the other hand, has the smallest estimates when the shocks are extracted using either the VECM or HP filter approaches. The diverse output losses imply that the three Greater China economies can have different views on the prospect of forming a common currency union. China, for instance, has the lowest output cost and is likely to be more susceptible to the notion of a Greater China currency union than the other two economies.

Fourth, there may be a debate on how to define the currency union shock. It is conceivable that China, the largest economy in the group, would prefer the policy abating the average of GDP-weighted shocks while Hong Kong, which is the smallest in the group, would favor the one that focuses on the simple average. In the case of China, the output loss estimates are always smaller when the GDP-weighted average is used. The opposite is true for Hong Kong. The result is quite intuitive because under the GDPweighted average definition, the stabilization policy is more responsive to shocks originated in a large economy. The Taiwan case is slightly different - its preference of the GDP-weighted average shock or the simple average shock depends on which shockextraction method is considered. For Taiwan, the notion of the GDP-weighted average shock is better under both the VECM and HP filter but not under the BQ setting. One possible way for China to persuade the other two economies to adopt the criterion of a GDP-weighted average shock is to re-distribute its gain to the other two economies. Such a possibility will be considered when we examine output losses in monetary terms.

Fifth, the output loss of Greater China as an entity should be considered if the economies can compromise and reach a mutually agreeable re-distribution scheme. The figures reported under the row heading "Greater China" are quite small. There are only two cases in which the percentage output loss is larger than $0.5 \%$, and two other cases in which the loss is larger than $0.3 \%$. These high-end loss estimates are comparable to some estimates of the benefits of a currency union. For example, in an earlier study (Commission of the European Communities, 1990), it is estimated that the cost savings 
for the European countries to adopt a single currency are between $0.3 \%$ to $0.4 \%$ of the aggregate GDP. The benefit of price convergence, which is a plausible consequence of creating a currency union, is $0.55 \%$ of the world GDP (Hufbauer et al., 2002). Further, we should recall that the output loss is derived under the assumption that individual monetary authorities can perfectly fine-tune their economies and, thus, the output loss should be properly interpreted as an upper bound of potential losses. Thus, if a common currency for the three Greater China economies generates a similar magnitude of savings, then the benefits of forming a currency union can outweigh the estimated output losses.

If shocks are accurately estimated by the VECM or the BQ method, Greater China will prefer the policy of managing the GDP-weighted average of shocks to individual economies because such a policy leads to a smaller percentage output loss. However, if the HP filter yields better estimates of shocks, then it is beneficial to pursue the policy of managing the simple average of shocks to individual economies. Thus, the results reinforce the relevance of the choice of shock-estimation method in evaluating issues related to a currency union.

The loss estimates in Table 7 are derived from a range of labor share values. It is instructive to consider the losses corresponding to some "reasonable" estimates of labor shares in these economies. In her recent study, Harrison (2002) provides labor share estimates for a large number of economies. In this exercise, we adopt her 1993-1996 labor share figures and calculate the corresponding output losses. Specifically, the labor share parameter is set to 0.36 for China and 0.49 for Hong Kong and Taiwan. ${ }^{15}$

The output losses calculated based on the specific set of labor shares are presented in Table 8. If the selected labor share figures are consistent with the economic structures of the three Greater China economies, then the output cost of forming a currency union is lower than the potential benefit estimated in Commission of the European Communities (1990). While the potential gain can offset the potential loss in forming a currency union, there is a re-distribution issue. As evidenced in the Table, the output loss of Hong Kong can be quite high - more than $0.7 \%$ according to the HP filter approach under the GDPweighted average policy. At the same time, a small economy is likely to achieve a low

15 We assume China is a member of Harrison's "bottom-middle" income group, and Hong Kong and Taiwan are members of the "upper middle" income group. 
level of cost savings from gain in economic efficiency and reduction in transaction costs. Thus, without an appropriate re-distribution scheme or other economic incentives, a small economy may not elect to join the union because the cost can be higher than the benefit. ${ }^{16}$ Obviously, there are other (economic and political) factors affecting the decision of joining a currency union. Nonetheless, our discussion offers one perspective to evaluate the situation.

Table 8. $\quad$ Estimated Average Output Losses in Percentages Based on a Specific Set of Labor Share Values

\begin{tabular}{|c|c|c|c|c|c|c|}
\hline & \multicolumn{3}{|c|}{$\begin{array}{l}\text { GDP-Weighted Average of } \\
\text { Shocks }\end{array}$} & \multicolumn{3}{|c|}{ Simple Average of Shocks } \\
\hline & VECM & HP Filter & $\underline{B Q}$ & VECM & HP Filter & $\underline{B Q}$ \\
\hline China & 0.034 & 0.068 & 0.018 & 0.051 & 0.099 & 0.036 \\
\hline Hong Kong & 0.256 & 0.716 & 0.197 & 0.225 & 0.509 & 0.159 \\
\hline Taiwan & 0.210 & 0.363 & 0.018 & 0.184 & 0.215 & 0.027 \\
\hline $\begin{array}{l}\text { Greater } \\
\text { China }\end{array}$ & 0.096 & 0.204 & 0.042 & 0.100 & 0.171 & 0.052 \\
\hline
\end{tabular}

Note: The percentage output loss estimates are based on the labor share values: 0.36 for China and 0.49 for both Hong Kong and Taiwan (Harrison, 2002). See the "Note" to Table 7 for detail.

The output losses in billions of 1994 US dollar are presented in Tables 9 and 10. Table 9 gives the loss estimates from a range of labor share values and Table 10 contains estimates from the selected set of labor share figures for the three Greater China economies. The patterns of output losses are similar to those in Tables 7 and 8. For instance, the output loss increases with the labor share parameter, the shocks calculated from the HP filter yield the largest loss estimates, and those from the BQ approach yield the smallest estimates.

16 For instance, an early access of the huge Chinese market can provide a strong incentive for Hong Kong to join a Greater China currency union. 
Table 9. $\quad$ Estimated Average Output Losses in Billions of US Dollar

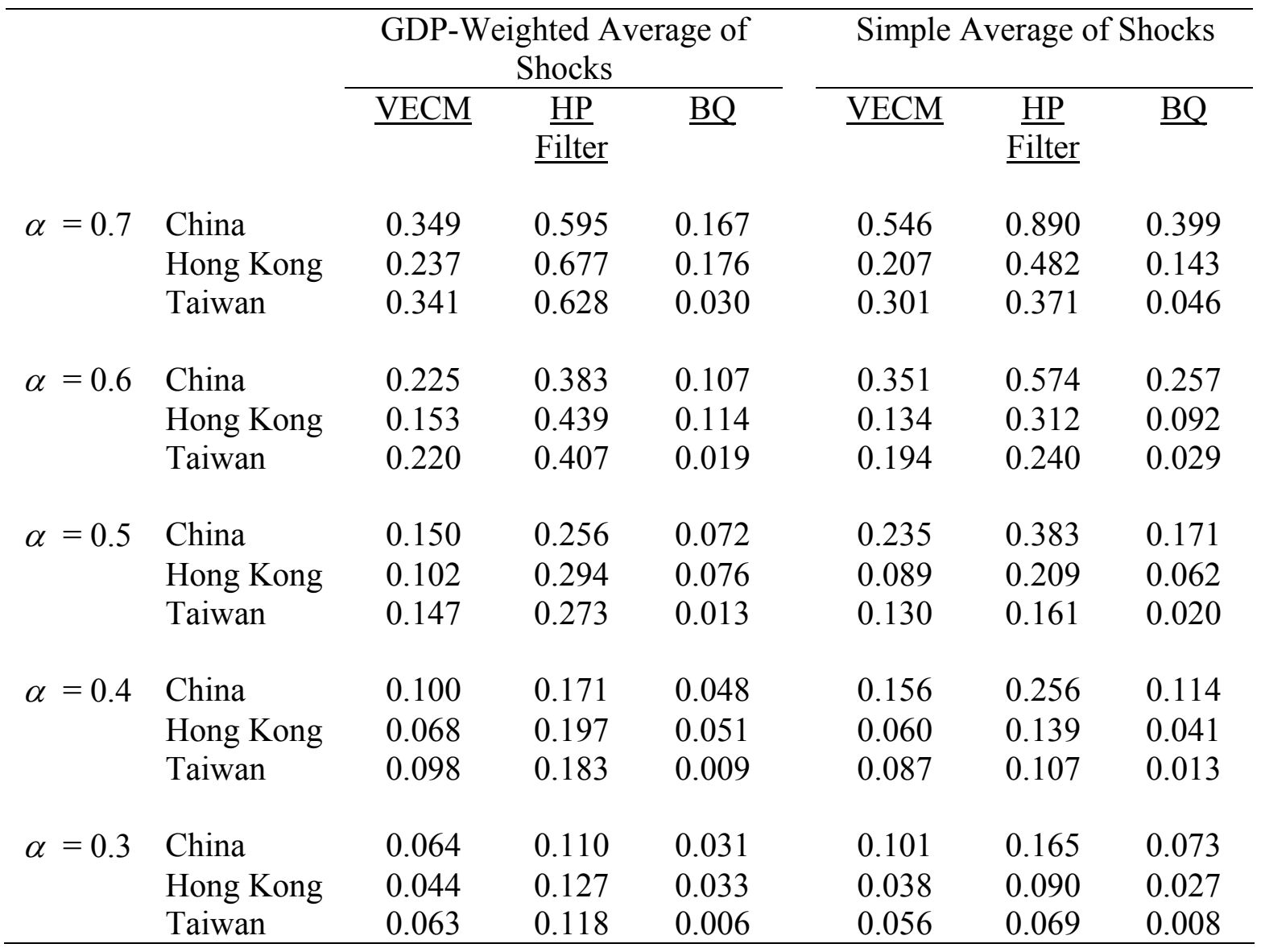

Note: The estimated average output losses in billions of US dollar are reported. See the "Note" to Table 7 for detail.

Table 10. Estimated Average Output Losses in billions of US dollar Based on a Specific Set of Labor Share Values

\begin{tabular}{|c|c|c|c|c|c|c|}
\hline & \multicolumn{3}{|c|}{$\begin{array}{c}\text { GDP-Weighted Average of } \\
\text { Shocks }\end{array}$} & \multicolumn{3}{|c|}{ Simple Average of Shocks } \\
\hline & $\underline{\mathrm{VECM}}$ & HP Filter & $\underline{\mathrm{BQ}}$ & $\underline{\mathrm{VECM}}$ & HP Filter & $\underline{\mathrm{BQ}}$ \\
\hline China & 0.084 & 0.144 & 0.040 & 0.132 & 0.216 & 0.096 \\
\hline Hong Kong & 0.098 & 0.283 & 0.073 & 0.086 & 0.201 & 0.059 \\
\hline Taiwan & 0.141 & 0.262 & 0.012 & 0.125 & 0.154 & 0.019 \\
\hline
\end{tabular}

Note: The estimated average output losses in billions of US\$ are based on the labor share values: 0.36 for China and 0.49 for both Hong Kong and Taiwan (Harrison, 2002). See the "Note" to Table 7 for detail. 
With the loss expressed in monetary terms, we can assess if, say, China has the incentive to pay the other two economies to adopt the policy of smoothing the GDPweighted average of individual shocks. For results in both Tables 9 and 10, the answer depends on which shock-extraction method is used to calculate the output losses. If either the VECM or the BQ method is used, then China's gain from adopting the GDPweighted average instead of the simple average target is large enough to offset the corresponding losses incurred by Hong Kong and Taiwan. However, if the HP filter is used, then Hong Kong and Taiwan together have an incentive to pay off China to adopt the policy of managing the simple average of individual shocks.

Overall, the loss calculation reveals that possible output losses resulting from forming a Greater China currency union are moderate. Further, the estimated losses are likely to be smaller than the potential gains of forming a currency union estimated by some previous studies. Arguably, these loss estimates and the results presented in the previous sections are supportive of the notion of a Greater China currency union.

\section{Concluding Remarks}

The three Greater China economies namely China, Hong Kong, and Taiwan have experienced a rapid pace of integration since China launched economic reforms two decades ago. This paper assesses the current level of integration and investigates whether the three Greater China economies are suitable for a currency union. Currently, the three economies have extensive trade and investment linkages. Our analyses show that these economies share common long-run and short-run cyclical variations. The potential output costs of relinquishing policy autonomy seem to be moderate and are likely to be less than the efficient gains derived from a currency union arrangement. ${ }^{17}$ Further, some extant studies (Corestti and Pesenti, 2002; Frankel and Rose, 1998; Engel and Rose, 2002) show that the implementation of a currency union can induce structural changes that facilitate integration and increase the strength of common business cycles. While our focus is the suitability of a Greater China currency union, our results are complementary to other 
studies that, using different approaches, infer Asian economies are not unsuitable for a currency union.

Despite the positive evidence, it is fair to consider the hurdles along the path to a currency union. Eichengreen (2001) and Wyplosz (2002), for example, point out that the making of a currency union goes beyond the economic preconditions, and the Asian region lacks a) the tradition, b) the institutional setting, and c) the political climate to facilitate integration. These issues are relevant to the discussion of a Greater China currency union. For instance, segments of populations in these economies are quite agonistic about the legacies of war, differences in political structures, and communism. The escalated political squabbles between China and Taiwan and the desire for democracy expressed by Hong Kong people, for instance, are likely to create undulations along the path to a currency union. Another challenge is the costs of adjustment. China, Hong Kong, and Taiwan are at different stages of economic development. The difference can lead to huge gains from trade and integration and, at the same time, create serious adjustment problems. For instance, it is believed that China has hollowed out the manufacture sector in Hong Kong and a similar process is happening to the manufacture sector in Taiwan.

There are both economic and non-economic obstacles to form a Greater China currency union in the near term. However, the prospect is quite encouraging. China, Hong Kong, and Taiwan have common history, culture, and language, and share an extensive kinship network. These are good catalysts for integration. For both historical reasons and political reality, China has a stronger link with Hong Kong than with Taiwan. It is conceivable that the pace of integration between China and Hong Kong will be enhanced by their 2003 Closer Economic Partnership Arrangement and the on-going discussion on the development of the Pearl River Delta economic region.

There are differences between China and Taiwan. However, it is hard to perceive these differences will last for too long and significantly hinder economic interactions between China and Taiwan. Given the existing economic ties, any severe political and military conflicts can inflict a huge cost on both economies. Even though she is agonistic

17 One caveat is in order. The empirical results are derived from existing data. Given the rapid developments in these countries; especially in China, the future could look very different from 
about Taiwan's attempts to engage in any bilateral and multilateral trade agreement as a sovereign country, China is willing to negotiate a trade agreement with Taiwan. ${ }^{18}$ As mentioned earlier, the current integration process between the three Greater China economies is proceeding more along de facto than de jure lines. Usually, institutional changes are made to accommodate economic developments in these economies. There is a possibility that the road to a Greater China currency union is led by economic considerations rather than politics. 


\section{References}

Alesina, Alberto, Robert J. Barro, and Silvana Tenreyro, 2002, “Optimal Currency Areas,” NBER Working Paper \#9072.

Baxter, Marianne and Alan C. Stockman, 1989, "Business cycles and the exchange-rate regime: Some international evidence," Journal of Monetary Economics 23, 377-400.

Bayoumi, Tamim and Barry J. Eichengreen, 1994, "One Money or Many? Analyzing the Prospects of Monetary Unification in Various Parts of the World," Princeton Studies in International Finance No. 76.

Bayoumi, Tamim and Barry J. Eichengreen, 1999, "Operationalizing the Theory of Optimum currency Areas," in R.E Bldwin, D. Cohen, A. Sapir, and A.J. Venables (eds.), Market Integartion, Regionalism, and the Global Economy, 187-227, Cambrigde: Cambridge University Press.

Bayoumi, Tamim and Paolo Mauro, 1999, “The Suitability of ASEAN for a Regional Currency Arrangement," IMF Working Paper 99/162.

Bergsten, C. Fred and Park, Yung Chul, 2002, “Toward Creating a Regional Monetary Arrangement in East Asia,” ADB Institute Research Paper Series No. 50.

Blanchard, Oliver J. and Danny Quah, 1989, "The Dynamic Effects of Demand and Supply Disturbances," American Economic Review 79, 655-673.

Brown, Drusilla K., Alan V. Deardorff and Robert M. Stern, 2002, "CGE Modeling and Analysis of Multilateral and Regional negotiating Options," in Robert M. Stern (editor), Issues and options for U.S.-Japan trade policies, 23- 65, Ann Arbor: University of Michigan Press.

Canova, Fabio, 1998, "Detrending and Business Cycle Facts," Journal of Monetary Economics 41, 475-512.

Cheung, Yin-Wong and Kon S. Lai, 1993, “Finite Sample Sizes of Johansen's Likelihood Ratio Tests for Cointegration," Oxford Bulletin of Economics and Statistics 55, 313-328.

Cheung, Yin-Wong and Kon S. Lai, 1995, "Lag order and Critical Values for the Augmented Dickey-Fuller Test," Journal of Business \& Economic Statistics 13, 277-280.

Commission of the European Communities, 1990, “One Market, One Money,” European Economy 44, Office for Official Publications of the European Communities.

Corestti, Giancarlo, Paolo Pesenti, 2002, “Self-Validating Optimum Currency Areas," manuscript presented in the 2002 SCIII conference, UCSC. 
Eichengreen, Barry J. and Tamim Bayoumi, 1999, "Is Asia an Optimum Currency Area? Can It Become One? Regional, Global and Historical Perspectives on Asian Monetary Relations," in Stefan Collignon, Jean Pisani-Ferry and Yung Chul Park (eds.), Exchange Rate Policies in Emerging Asian Countries, 347-366, London and New York: Routledge.

Eichengreen, Barry J. 2001, "Hanging together? On Monetary and Financial Cooperation in Asia," Manuscript, UC Berkeley.

Engle, Robert. F. and Susan Kozicki, 1993, "Testing for Common Features," Journal of Business and Economics Statistics 11, 369-379.

Engel, Charles and Andrew K. Rose 2002, "Currency Unions and International Integration," Journal of Money Credit and Banking 34, 1067-1089.

Frankel, Jeffrey A. and Andrew K. Rose 1998, “The Endogeneity of the Optimum Currency Area Criteria," Economic Journal 108, 1009-1025.

General Agreement on Tariffs and Trade, 1994, "Report on the Informal Group of Experts on Export Statistics - Final Report."

Ghosh, Atish R. and Holger C. Wolf, 1994, "How Many Monies? A Genetic Approach to Finding Optimum Currency Areas,” NBER Working Paper\# 4805.

Granger, Clive W.J. and Jin-Lung Lin, 1995, "Causality in the Long Run,” Econometric Theory 11, 530-536.

Harding, Harry, 1993, “The Concept of 'Greater China': Themes, Variations and Reservations,” China Quarterly, issue 136, pp. 660-686.

Harrison, Ann E., 2002, "Has Globalization Eroded Labor's Shares? Some Cross-Country Evidence," manuscript, University of California at Berkeley.

Harvey, A.C. and A. Jaeger, 1993, "Detrending, Stylized Facts and the Business Cycle,” Journal of Applied Econometrics 8, 231-247.

Henning, C. Randall, 2002, East Asian Financial Cooperation, Policy Analyses in International Economics 68, Washington: Institute for International Economics.

Hufbauer, Gary C., Erika Wada and Tony Warren, 2002, The Benefits of Price Convergence: Speculative Calculations, Policy Analyses in International Economics 63, Washington: Institute for International Economics.

International Monetary Fund, 1995, “People's Republic of China - Staff Report for the 1994 Article IV Consultant, Annex IV,’ Washington: International Monetary Fund. 
Johansen, Soren, 1991, "Estimation and Hypothesis Testing of Cointegration Vectors in Gaussian Vector Autoregressive Models," Econometrica 59, 1551-1581.

Johansen, Soren and Katarina Juselius, 1990, "Maximum Likelihood Estimation and Inference on Cointegration - with Applications to the Demand for Money," Oxford Bulletin of Economics and Statistics 52, 169-210.

Jones, Randall, Robert King and Michael Klein, 1992, „The Chinese Economic Area: Economic Integration Without a Free Trade Agreement,“ OECD Working Paper \#124.

Lafrance, Robert and Pierre St-Amant, 1999, “Optimum Currency Areas: A Review of the Recent Literature," Bank of Canada Working Paper 99-16.

Lee, Jong-Wha, Yung Chul Park and Kwanho Shin, 2002, "A Currency Union in East Asia," manuscript, Korea University.

Maddison, Angus, 1998, Chinese Economic Performance in the Long Run, Paris: Organization for Economic Cooperation and Development.

McKinnon, Ronald and Gunther Schnabl, 2003, "Synchronized Business Cycles in East Asia and Fluctuations in the Yen/Dollar Exchange Rate," forthcoming, The World Economy.

Mundell, Robert, 1961, “A Theory of Optimum Currency Areas,” American Economic Review 51, 657-665.

Naughton, Barry (ed.), 1997, China Circle: Economics \& Technology in the PRC, Taiwan, \& Hong Kong, Washington, DC: Brookings Institution.

Ng, Thiam Hee, 2002, "Should the Southeast Asian Countries form a Currency Union?" The Developing Economies XL, 113-34.

People’s Daily Online, 2003, “China's Mainland-Taiwan Trade Agreement Proposed," http://english.peopledaily.com.cn/200307/20/print20030720_120652.html

Scollay, Robert and John P. Gilbert, 2001, New Regional Trading Arrangement in the Asia Pacific, Policy Analyses in International Economics 63, Washington: Institute for International Economics.

Tsang, S.-K., 2002, “Optimum currency area for Mainland China and Hong Kong? Empirical Tests," HKIMR Working Paper No.16/2002.

Vahid, Farshid and RRobert F. Engle, 1993, “Common Trends and Common Cycles," Journal of Applied Econometrics 8, 341-360. 
Vahid, Farshid and Robert F. Engle, 1997, "Codependent Cycles," Journal of Econometrics 80, 199-221.

World Bank, 1997, China Engaged: Integration with the Global Economy, Washington, D.C.: World Bank.

Wyplosz, Charles, 2002, “A Monetary Union in Asia? Some European Lessons,” in David Gruen and John Simon (eds.), Future Directions for Monetary Policies in East Asia, Reserve Bank of Australia, 124-155. 


\section{CESifo Working Paper Series}

(for full list see www.cesifo.de)

1127 Henrik Christoffersen and Martin Paldam, Privatization in Denmark, 1980-2002, February 2004

1128 Gregory S. Amacher, Erkki Koskela and Markku Ollikainen, Deforestation, Production Intensity and Land Use under Insecure Property Rights, February 2004

1129 Yin-Wong Cheung, Javier Gardeazabal, and Jesús Vázquez, Exchange Rate Dynamics: Where is the Saddle Path?, February 2004

1130 Alberto Alesina and Guido Tabellini, Bureaucrats or Politicians?, February 2004

1131 Gregory S. Amacher, Erkki Koskela, and Markku Ollikainen, Socially Optimal Royalty Design and Illegal Logging under Alternative Penalty Schemes, February 2004

1132 David M. Newbery, Privatising Network Industries, February 2004

1133 Charles Yuji Horioka, The Stagnation of Household Consumption in Japan, February 2004

1134 Eiji Fujii, Exchange Rate Pass-Through in the Deflationary Japan: How Effective is the Yen's Depreciation for Fighting Deflation?, February 2004

1135 Mark M. Spiegel and Nobuyoshi Yamori, Determinants of Voluntary Bank Disclosure: Evidence from Japanese Shinkin Banks, Febrary 2004

1136 Robert Dekle and Kenneth Kletzer, Deposit Insurance, Regulatory Forbearance and Economic Growth: Implications for the Japanese Banking Crisis, February 2004

1137 Takatoshi Ito and Kimie Harada, Bank Fragility in Japan, 1995-2003, February 2004

1138 Kunio Okina and Shigenori Shiratsuka, Policy Duration Effect under Zero Interest Rates: An Application of Wavelet Analysis, February 2004

1139 Francine D. Blau and Lawrence M. Kahn, Do Cognitive Test Scores Explain Higher U.S. Wage Inequality?, February 2004

1140 Michael Rauscher, Economic Growth and Tax-Competing Leviathans, February 2004

1141 Ernst Fehr and Jean-Robert Tyran, Money Illusion and Coordination Failure, February 2004

1142 Ingo Vogelsang, Network Utilities in the U.S. - Sector Reforms without Privatization, March 2004 
1143 Marc-Andreas Muendler, Estimating Production Functions When Productivity Change is Endogenous, March 2004

1144 Sascha O. Becker, Samuel Bentolila, Ana Fernandes, and Andrea Ichino, Job Insecurity and Children's Emancipation, March 2004

1145 Pascalis Raimondos-Møller and Alan D. Woodland, Non-Preferential Trading Clubs, March 2004

1146 Robert Fenge and Matthias Wrede, EU Regional Policy: Vertical Fiscal Externalities and Matching Grants, March 2004

1147 Chi-Yung Ng and John Whalley, Geographical Extension of Free Trade Zones as Trade Liberalization: A Numerical Simulation Approach, March 2004

1148 Marc-Andreas Muendler, Trade, Technology, and Productivity: A Study of Brazilian Manufacturers, 1986-1998, March 2004

1149 Eugene Beaulieu, Vivek H. Dehejia, and Hazrat-Omar Zakhilwal, International Trade, Labour Turnover, and the Wage Premium: Testing the Bhagwati-Dehejia Hypothesis for Canada, March 2004

1150 Giorgio Brunello and Francesca Gambarotto, Agglomeration Effects on EmployerProvided Training: Evidence from the UK, March 2004

1151 S. Brock Blomberg, Gregory D. Hess, and Athanasios Orphanides, The Macroeconomic Consequences of Terrorism, March 2004

1152 Bodo Sturm and Joachim Weimann, Unilateral Emissions Abatement: An Experiment, March 2004

1153 Wolfgang Ochel, Welfare-to-Work Experiences with Specific Work-First Programmes in Selected Countries, March 2004

1154 Jan K. Brueckner and Eric Pels, European Airline Mergers, Alliance Consolidation, and Consumer Welfare, March 2004

1155 Aaron Tornell, Frank Westermann, and Lorenza Martínez, NAFTA and Mexico's Economic Performance, March 2004

1156 George Economides, Sarantis Kalyvitis, and Apostolis Philippopoulos, Do Foreign Aid Transfers Distort Incentives and Hurt Growth? Theory and Evidence from 75 Aid-recipient Countries, March 2004

1157 Robert Fenge and Volker Meier, Are Family Allowances and Fertility-related pensions Siamese Twins?, March 2004

1158 Bruno S. Frey, Simon Luechinger, and Alois Stutzer, Valuing Public Goods: The Life Satisfation Approach, March 2004 
1159 Jerome L. Stein and Guay C. Lim, Asian Crises: Theory, Evidence, Warning-Signals, March 2004

1160 Romain Ranciere, Aaron Tornell, and Frank Westermann, Crises and Growth: A ReEvaluation, March 2004

1161 Assaf Razin and Efraim Sadka, Transparency, Specialization and FDI, March 2004

1162 Ludger Woessmann, How Equal Are Educational Opportunities? Family Background and Student Achievement in Europe and the United States, March 2004

1163 B.M.S. van Praag and Barbara E. Baarsma, Using Happiness Surveys to Value Intangibles: The Case of Airport Noise, March 2004

1164 Aaron Tornell, Frank Westermann, and Lorenza Martínez, The Positive Link Between Financial Liberalization, Growth, and Crises, March 2004

1165 Helge Berger and Carsten Hefeker, One Country, One Vote? Labor Market Structure and Voting Rights in the ECB, March 2004

1166 Clemens Fuest and Martin Kolmar, A Theory of User-Fee Competition, March 2004

1167 Friedrich Schneider and Robert Klinglmair, Shadow Economies around the World: What Do We Know?, April 2004

1168 Horst Raff and Nicolas Schmitt, Exclusive Dealing and Common Agency in International Markets, April 2004

1169 M. Hashem Pesaran and Allan Timmermann, Real Time Econometrics, April 2004

1170 Sean D. Barrett, Privatisation in Ireland, April 2004

1171 V. Anton Muscatelli, Patrizio Tirelli and Carmine Trecroci, Can Fiscal Policy Help Macroeconomic Stabilisation? Evidence from a New Keynesian Model with Liquidity Constraints, April 2004

1172 Bernd Huber and Marco Runkel, Tax Competition, Excludable Public Goods and User Charges, April 2004

1173 John McMillan and Pablo Zoido, How to Subvert Democracy: Montesinos in Peru, April 2004

1174 Theo Eicher and Jong Woo Kang, Trade, Foreign Direct Investment or Acquisition: Optimal Entry Modes for Multinationals, April 2004

1175 Chang Woon Nam and Doina Maria Radulescu, Types of Tax Concessions for Attracting Foreign Direct Investment in Free Economic Zones, April 2004

1176 M. Hashem Pesaran and Andreas Pick, Econometric Issues in the Analysis of Contagion, April 2004 
1177 Steinar Holden and Fredrik Wulfsberg, Downward Nominal Wage Rigidity in Europe, April 2004

1178 Stefan Lachenmaier and Ludger Woessmann, Does Innovation Cause Exports? Evidence from Exogenous Innovation Impulses and Obstacles, April 2004

1179 Thiess Buettner and Johannes Rincke, Labor Market Effects of Economic Integration The Impact of Re-Unification in German Border Regions, April 2004

1180 Marko Koethenbuerger, Leviathans, Federal Transfers, and the Cartelization Hypothesis, April 2004

1181 Michael Hoel, Tor Iversen, Tore Nilssen, and Jon Vislie, Genetic Testing and Repulsion from Chance, April 2004

1182 Paul De Grauwe and Gunther Schnabl, Exchange Rate Regimes and Macroeconomic Stability in Central and Eastern Europe, April 2004

1183 Arjan M. Lejour and Ruud A. de Mooij, Turkish Delight - Does Turkey's accession to the EU bring economic benefits?, May 2004

1184 Anzelika Zaiceva, Implications of EU Accession for International Migration: An Assessment of Potential Migration Pressure, May 2004

1185 Udo Kreickemeier, Fair Wages and Human Capital Accumulation in a Global Economy, May 2004

1186 Jean-Pierre Ponssard, Rent Dissipation in Repeated Entry Games: Some New Results, May 2004

1187 Pablo Arocena, Privatisation Policy in Spain: Stuck Between Liberalisation and the Protection of Nationals' Interests, May 2004

1188 Günter Knieps, Privatisation of Network Industries in Germany: A Disaggregated Approach, May 2004

1189 Robert J. Gary-Bobo and Alain Trannoy, Efficient Tuition Fees, Examinations, and Subsidies, May 2004

1190 Saku Aura and Gregory D. Hess, What's in a Name?, May 2004

1191 Sjur Didrik Flåm and Yuri Ermoliev, Investment Uncertainty, and Production Games, May 2004

1192 Yin-Wong Cheung and Jude Yuen, The Suitability of a Greater China Currency Union, May 2004 